DOI: https://doi.org/10.11144/Javeriana.upsy19.sags

\title{
Spanish Adaptation of the Groningen Sleep Quality Scale (GSQS-8)*
}

\section{Adaptación Española de la Escala de Sueño de Groningen (GSQS-8)}

\section{María-José Serrano-Fernández ${ }^{\mathrm{a}}$ \\ Universitat Rovira i Virgili, España \\ ORCID: https://orcid.org/0000-0003-0363-5522}

JOAN BOADA-Grau

Universitat Rovira i Virgili, España

ORCID: https://orcid.org/0000-0002-1907-6887

\section{Lluís RoBert-SENTÍs}

Universitat Rovira i Virgili, España

ORCID: https://orcid.org/0000-0003-2901-4265

Maria BoAda-Cuerva

Universitat Oberta de Catalunya, España

ORCID: https://orcid.org/0000-0003-1446-4490

Andreu Vigil-Colet

Universitat Rovira i Virgili, España

ORCID: https://orcid.org/0000-0003-3818-4514

Jordi Assens-SERRA

EADA Business School, España

ORCID: https://orcid.org/0000-0001-5006-4211

a Correspondence author. Email:
mariajose.serrano@urv.cat

How to cite: Serrano-Fernández, M. J., Boada-Grau, J., Robert-Sentís, L., Boada-Cuerva, M., Vigil-Colet, A., \& Assens-Serra, J. (2020). Spanish adaptation of the Groningen Sleep Quality Scale (GSQS-8). Universitas Psychologica, 19, 1-11. https://doi.org/10.11144/Javeri ana.upsy19.sags
Received: 07 July 2018 | Accepted: 08 November 2021

\begin{abstract}
Professional drivers are a group susceptible to sleep problems or incorrect rest patterns resulting from work stress that causes alterations in biological stress markers, such as cortisol, or in cardiovascular parameters that show a state of physiological hyper-activation. The current research objective was to adapt and validate the Groningen Sleep Scale (Meijman et al., 1990) in a Spanish population. We analysed its internal structure, reliability and evidence of validity. The participants in this study were 372 drivers (93.4\% men, 6.6\% women), with a mean age of $40.9(\mathrm{SD}=10.54)$, obtained through non-probabilistic sampling. The SPSS 23.0 and AMOS (5.0) programs were used. With the confirmatory factor analysis (CFA) of the AMOS program (5.0), the indicators NFI $=0.902 ; \mathrm{TLI}=0.844$; $\mathrm{CFI}=0.913 ; \mathrm{RMSEA}=0.129$ were obtained and showed an acceptable adjustment of the unifactorial model with 8 items. Adequate reliability (0.90) and appropriate evidence of validity with TDS-38, MBI-GS, Irritation, MP-9, DII, and Trans-18. We can conclude that the Groningen Sleep Scale (GSQS-8) is a reliable and valid instrument, suitable in the Spanish language for evaluating the sleep quality of professional drivers.

Keywords

sleep quality scale; insomnia; subjective quality of sleep; drivers; fatigue.
\end{abstract}

\section{RESUMEN}

Los conductores profesionales son un colectivo susceptible de padecer problemas para dormir, o un descanso incorrecto, siendo esto debido a la tensión laboral que ocasiona alteraciones en los marcadores biológicos de estrés como es el caso del cortisol o en parámetros cardiovasculares que muestran un estado de hiperactivación fisiológica. Nuestro objetivo fue la adaptación de la Groningen Sleep Scale (Meijman et al., 1990) en la población española, así como el análisis de su estructura interna, fiabilidad e indicios de validez. Los participantes en este estudio han sido 372 
conductores (93.4\% hombres, $6.6 \%$ mujeres), con una media de edad de $40.9(S D=10.54)$, obtenidos mediante un muestreo no probabilístico. Se han utilizado los programas SPSS 23.0 y AMOS (5.0). Mediante análisis factorial confirmatorio, a partir del programa $\operatorname{AMOS}(5.0)$, se obtuvieron los siguientes indicadores NFI $=0.902$; TLI $=0.844 ; \mathrm{CFI}=0.913 ;$ RMSEA $=0.129$, indicando un ajuste aceptable del modelo unifactorial con 8 ítems. La fiabilidad es adecuada (0.90) y se muestran indicios de validez con: TDS-38, MBI-GS, Irritación, MP-9, DII y Trans-18. Por lo que podemos concluir que la Groningen Sleep Scale (GSQS-8), es un instrumento fiable y válido, adecuado, en lengua española, para evaluar la calidad del sueño en conductores profesionales.

Palabras clave

Escala de calidad del sueño; insomnio; calidad subjetiva del sueño; conductores; fatiga.

Professional drivers are a group with a high prevalence of psychosocial risks, unsafe behaviour in their jobs, and a higher risk of road mortality. Taylor and Dorn (2006) state that, apart from the effects on health, stress and fatigue in bus drivers can increase the risk of accidents. Driving fatigue is one of the most common risk factors related to traffic accidents ( $\mathrm{Li}$ et al., 2019; Li et al., 2018; Useche et al., 2017). Factors such as time pressures, long working hours and responsibility for the safety of passengers can also cause stress (Berrones \& González, 2018). General Director of Traffic (DGT, 2006) reported good practices and recommendations to be considered in the passenger transport sector (e.g., using motorway rest areas to rest). According to the General Directorate of Traffic (DGT, 2018), in Spain, sleep and fatigue were the leading cause in 2017 of 2,722 traffic accidents, with specifically 177 deaths and 4,063 injured victims, which 589 required hospitalization. Åkerstedt et al. (2002;2004) also showed a significant negative correlation between work stress and sleep quality. This is because the subjects exposed to stress at work show alterations in biological stress markers, such as cortisol, or in cardiovascular parameters that show a state of physiological hyper-activation (Moya-Albiol et al., 2005). Likewise Davidović et al. (2018) determined three factors that influence fatigue: 1) work factors, such as working long hours without having time to recover; 2) sleep factors, such as the alteration of circadian rhythms (driving at times when you usually sleep or vice versa), as well as the number of hours slept; and 3) other health factors such as sleep, health, or lifestyle problems.

In addition, some authors (Gosselin et al., 2005; Miró \& Buela-Casal, 2005) indicate that lack of sleep or altered sleep patterns generate fatigue, alter moods, worsen performance and produce changes in numerous bodily and immunosuppression systems. For transport professionals, sleep dysfunctions are related to work stress and working hours (Åkerstedt et al., 2002), resulting in fatigue (Åkerstedt et al., 2004) and affecting performance (Bonnet, 1985). Some studies have found that bus drivers experience poor sleep quality, which is of great concern for public safety and passengers alike (Chaiard et al., 2019; Sunwoo et al., 2017).

A significant sign of sleep disturbance is the presence of physiological or cognitive arousal at the time of going to sleep, as indicated by Åkerstedt et al. (2002). Also, workplace worries at bedtime influence the quality of sleep (Kecklund \& Åkerstedt, 2004). A later study by $\AA$ kerstedt et al. (2004) indicated that the most powerful predictor of mental fatigue, a manifestation closely related to burnout, is sleep alteration. In this line, McVicar (2003) suggests that the absence of sleep may be a premise prior to burnout.

Sleeping is a neurobiological need, relieved with waking states in predetermined cycles (Michael, 2017). When there are sleep disturbances, sleepiness deteriorates the psychomotor and neurocognitive functional variables such as reaction time, the capacity for surveillance, judgment and attention, and information processing. The alteration of these variables may lead to an increase in traffic accidents (Connor et al., 2002) and an increase in work accidents for the operators of machines with a potential for dangerous situations. Drowsiness increases the likelihood of the driver nodding, or falling asleep, and decreases the ability to manoeuvre the vehicle (Filtness et al., 
2014), resulting in significant losses in lives and infrastructures (Hillman et al., 2018).

The Groningen Sleep Quality Scale (GSQS-15; Meijman et al., 1990) evaluates the subjective quality of sleep, covering the following complaints: the general quality of sleep, insufficient sleep, problems of falling asleep, problems sleeping and waking up feeling unrested. It is, therefore, a beneficial instrument for assessing the quality of sleep in professional drivers. Sluiter et al. (1999) showed that the need to rest was an important predictor of psychosomatic complaints as well as complaints about sleep and emotional exhaustion in coach drivers. The need for rest is a sign of occupationally induced fatigue leading to health complaints and work stress.

The original scale was created in Dutch to assess sleep problems in depressed patients (Mulder-Hajonides van der Meulen, 1990). Meijman et al. (1988) validated the scale in a sample of shift workers, obtaining an $\alpha=0.89$. The scale has been translated into Parsi with $\alpha=$ 0.88 (Jafarian et al., 2008) and Hungarian with $\alpha$ $=0.85$ (Simor et al., 2009). This is the first time the scale is presented in Spanish. Based on the 15 items of the Groningen Sleep Scale by Meijman et al. (1990), the study had three objectives: The internal consistency evaluated with the exploratory factor analysis would distinguish the same component as the original Dutch scale. The factors extracted from the exploratory factor analysis would be replicated by confirmatory factor analysis. That the factors of the scale would have adequate reliability and that the factors of the scale would correlate with other variables, providing indications of convergent validity of the scale under study.

\section{Method}

\section{Participants}

The sample consisted of 372 Spanish professional drivers from the transport sector $(93.4 \%$ men, $6.6 \%$ women), with an average age of $40.9(S D=10.54)$. They included drivers involved in passenger transportation $33.3 \%$, freight transport $28.0 \%$, ambulances drivers $2.4 \%$, and taxi drivers $36.3 \%$; the average years of experience was $10.46(\mathrm{SD}=13.05)$. The average length of time they had been driving professionally was $10.46(S D=13.05)$. Marital status: Married or in a couple $(70.8 \%)$, single (21.2\%), divorced/ separated/ widowed (8.0\%). The distribution of education level was as follows: had not finished primary education (20.6\%), lower secondary school, professional training-II or primary school (21\%), upper secondary school, professional training-I or compulsory secondary education diploma (55.2\%), University studies (3.2\%).

\section{Instruments}

La Groningen Sleep Scale (GSQS -15; Meijman et al., 1990) was translated into Spanish using translation and "back translation" (Hambleton et al., 2005; Muñiz \& Bartram, 2007). This scale evaluates the subjective quality of sleep, covering the following complaints: the general quality of sleep, insufficient sleep, problems falling asleep, problems sleeping, and waking up feeling unrested. The Dutch version consists of 15 items, and its structure is unifactorial $(\alpha$ $=0.89)$. Six-point answers are applied $(1=$ Strongly disagree to $6=$ Strongly agree), e.g., "1. La pasada noche dormí profundamente [Last night I slept soundly]". The items are grouped so that a higher score on the scale means less subjective sleep quality.

The Trans Driver Stress (TDS-38; RobertSentís, 2016) is the Spanish version of the Bus Driver Stress Scale (BDS-59; Dorn et al., 2010). The TDS-38 uses a Likert scale of 6 points and consists of five factors: "F1. Relaxed Driving", refers to the distension or tension that the driver has while driving, as well as before and after driving (7 items, $\alpha=0.7$ ); "F2. Hazard Prevention", indicates the effort made while driving and the possible dangers that may be encountered while driving on the road (8 items, $\alpha=0.77)$; "F3. Alertness and vigilance", refers to the ease with which the driver can relax 
while driving or after it (6 items, $\alpha=0.7$ ); "F4. Search for Emotions", refers to the way of driving (5 items and $\alpha=0.8$ ); and "F5. Fatigue and Anxiety", indicates fatigue and the state of anxiety that driving causes in the driver $(12$ items, $\alpha=0.76$ ).

The Burnout scale (MBI-G; Salanova et al., 2000) assesses burnout and comprises 15 items (3 subscales). The subscale of "Exhaustion ( $\alpha$ $=0.87$ )" comprises 5 items (e.g., "6. Estoy 'quemado' por el trabajo [I am 'burned out' by work]"), that of "Cynicism $(\alpha=0.85)$ " consists of 5 items (e.g., "9. He perdido entusiasmo por mi trabajo [I have lost enthusiasm for my work]") and "Professional efficiency $(\alpha=0.78) "$ includes 6 items (e.g., "12. I have achieved many valuable things in this position"), with Likert-type responses of 7 points ranging from 0 . Never / Never to 6. Always / Every day.

The Irritation Scale (Mohr, 1986; Mohr et al., 2006), in its Spanish version, was adapted by Merino et al. (2006). This scale has 8 items and 2 subscales. The first subscale is called "F1. Emotional irritation" $(\alpha=0.86)$ and is composed of 5 items (e.g., "6. Me enfado con facilidad [I get angry easily]"); and the second one is called "F2. Cognitive Irritation" $(\alpha=0.87)$ and is composed of 3 items "(e.g.,"4. Incluso en vacaciones no puedo dejar de pensar a veces en los problemas del trabajo [Even on holidays, I can't stop thinking about work problems]"). The answers use a Likert scale of 7 points (from 1 . Strongly disagree to 6 . Strongly agree).

The version of Musculoskeletal Problems (MP-9; Robb \& Mansfield, 2007) adapted to Spanish by Robert-Sentís (2016) makes it possible to evaluate musculoskeletal problems and vibrations. It consists of 9 items, and their structure is bifactorial: "F1. Musculoskeletal aspects," refer to the body (e.g., shoulders), ( $\alpha$ $=0.72$ ). "F2. Extremities" (e.g., knees), consider the vibrations that indicate the comfort of the seat and the lumbar adjustment $(\alpha=0.7)$. It is answered with a Likert scale of five points $(1=$ Never and $5=$ Always).

The Trans-18 scale (TRANS-18; Boada-Grau et al., 2012) is for detecting safety behaviours (personal and in the vehicle) as well as psychophysiological disorders and includes 18 items (3 subscales). "F1. Psychophysiological disorders" of the driver $(\alpha=0.81)$ refer to the occurrence of anxiety, stress, digestive, depressive, musculoskeletal and hypertension disorders (e.g., 11. Mi trabajo me ha producido algún trastorno de depresión [My work has caused me a depression disorder]"). "F2. Personal safety behaviours" ( $\alpha=0.80$ ). e.g., not driving after drinking an alcoholic beverage or having eaten copiously, such as not eating and / or drinking while driving; it also refers to not smoking or talking on a mobile phone while driving (e.g., "7. Eludo conducir fumando y no tengo el cigarro, puro, purete,... en la mano [I avoid smoking while I drive and I don't hold a cigarette or cigar in my hand]"). "F3. Safety behaviour in the vehicle " $(\alpha=0.70)$ considers aspects such as using gloves to perform work activities, knowing how fire extinguishers work, and being attentive to driving and resting for the established number of hours (e.g., 3. Utilizo los guantes de trabajo cuando manipulo y cargo mercancías, cambio una rueda, etc. [I use work gloves when I handle the cargo, change a wheel, etc.]").

The Dickman's Impulsivity Inventory scale (DII; Dickman, 1990), in its Spanish version (Chico et al., 2003), consists of 23 items and 2 subscales, and the response format is dichotomous $(1=$ true / 0 = false): "F1. Functional Impulsivity" evaluates the impulsiveness that favours and helps us to adapt to unexpected situations that require a quick response. It consists of 11 items $(\alpha=0.77)$ (e.g., "5. La mayor parte del tiempo puedo concentrarme en mis trabajos de forma rápida [Most of the time I can concentrate on my work quickly]"). And "F2. Dysfunctional impulsivity" refers to that impulsivity that can cause problems and is formed by 12 items $(\alpha=$ 0.76), e.g., "2. Frecuentemente digo lo primero que se me ocurre sin pensar mucho antes [I often say the first thing that comes to mind without thinking much before]".

Other data were also collected, such as age, seat comfort, seat suspension, adjustable lumbar support for the driver's seat, and the number of driving hours. 
Procedure

We used non-probabilistic sampling (Hernández et al., 2004), also called random-accidental sampling (Kerlinger \& Lee, 2004), to obtain the sample.

To collect the data, we made telephone contact with the directors of several transport companies and agreed on the best moment to meet the drivers. We produced a booklet that included all the questionnaires to be used and instructions on how to complete them. A psychologist was responsible for collecting all the data at a particular company and ensuring that no questionnaire was missing any data. Several ethical guidelines were taken into account (Declaration of Helsinki, the Belmont Report, and the Council for International Organizations of Medical Sciences Guidelines), and all participants provided informed consent. The response rate was approximately $80 \%$.

\section{Data Analysis}

The AMOS Program (Analysis of Moment Structures) (version 5.0) makes it possible to analyse latent structures and create structural equations (SEM). This program makes it easier to specify, estimate, evaluate and present a model in an intuitive diagram that shows the possible relationships between the variables. Therefore, the validity of the model can be tested and confirmed. A step diagram can be elaborated, and modelling can obtain an immediate result concerning the 15 items applied in the program. The SPSS program (version 23.0) was used to calculate internal consistency (Cronbach's alpha) and evidence of convergent validity (Pearson correlations). Indications of validity were calculated using Pearson correlation coefficients between the subfactors of the scales (TDS-38, MBI-GS, Irritation, MP-9, and Trans-18) and the Groningen Sleep Scale (GSQS $-15)$.

\section{Results}

\section{Factorial analysis}

The results of the Bartlett sphericity test (Chisquare, $d f=20=55.123 ; p=0.00$ ) show that the AFE is appropriate (Kaiser, 1974). The sample adequacy is .936. Parallel analysis (Lattin et al., 2003; Timmerman \& Lorenzo-Seva, 2011) and the "minimum partial partial" criterion of Velicer (1976) confirmed that the eight-item unifactorial solution is adequate. The Promin rotation method was used to establish the EFA (Lorenzo-Seva, 1999). The variance explained was $44.90 \%$ (Table 1$)$.

\section{Table 1}

AFE (15 items): Matrix of saturations of the sleep quality scale factor (GSQS -15) and final items of the GSQS-8 scale

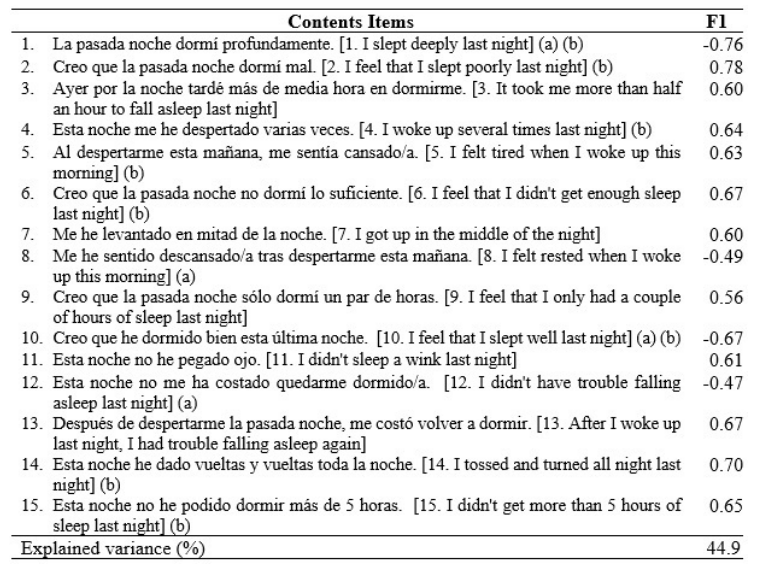

(a) Reverse items, (b) Definitive items of the scale derived from the AFC.

We applied a confirmatory factor analysis (CFA) to the 15 items in Meijman et al. (1990) to test the adequacy of the unifactorial structure of the original Dutch GSQS-15. The following goodness-of-fit indicators were used: NFI (Normed Fit Index), TLI (TuckerLewis Index), CFI (Comparative Fit Index), and RMSEA (Root Mean Square Error of Approximation).

For the cut-off points in the adjustment indexes of the structural models, there is certain unanimity that values equal to or higher than 0.90 in the Tucker-Lewis index, and 
the comparative adjustment index (CFI) are acceptable. They are considered excellent when they exceed a value of 0.95 (Lévy-Mangin \& Varela-Mallou, 2006). For its part, the average square root of approximation error (RMSEA) is considered acceptable when it is less than 0.08 and excellent when it is equal to or less than 0.05 (Bentler, 1990; Fan \& Sivo, 2007; Hu \& Bentler, 1999). Figure 1 shows the indicators that were obtained $(\mathrm{NFI}=0.902$, TLI $=0.844$, $\mathrm{CFI}=0.913$, RMSEA $=0.08)$. These indicate an acceptable adjustment of the model because all indices have values that are considered acceptable. The final items of the scale are shown in Table 1.

\section{Figure 1}

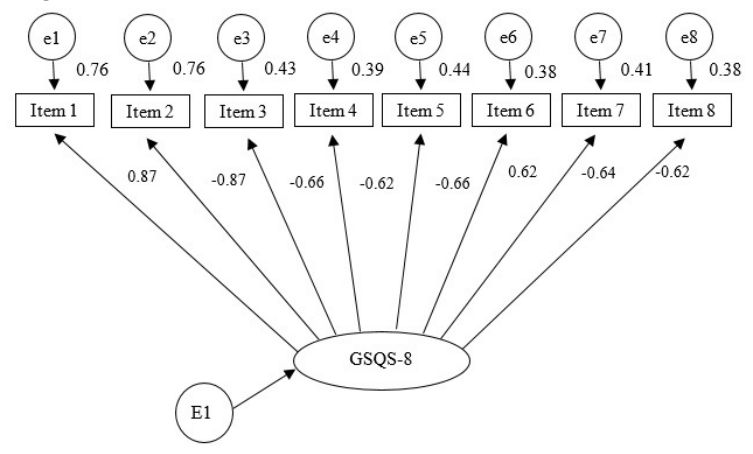

\section{Reliability}

Table 2 shows the mean, the standard deviation, the reliability coefficients, and the confidence intervals of the GSQS-8. The reliability of the scale is 0.90 with a $95 \%$ confidence interval of 88 to 0.92 . Therefore, the values were higher than the recommended value of 0.70 (Nunnally \& Bernstein, 1994).

Table 2

GSQS-8: Descriptive statistics, reliability, confidence intervals

\begin{tabular}{lr}
\hline \multicolumn{1}{c}{ Statistics } & F1 $(\mathbf{N}=\mathbf{3 7 2})$ \\
\hline Mean & 33.93 \\
SD & 14.94 \\
Reliability & 0.90 \\
Confidence Intervals & $0.88-0.92$ \\
\hline
\end{tabular}

\section{Evidence of validity}

Validity indicators were calculated using Pearson correlation coefficients between the subfactors of the scales (TDS-38, MBI-GS, Irritation, MP-9, DII and Trans-18) and the Groningen Sleep Scale (GSQS-8). External correlates were also used. Table 3 shows the correlations between the GSQS-8 factors and the different correlates and instruments. The external correlates used are associated with several factors, both directly and inversely.

Thus, GSQS-8 is positively associated with 13 correlates (days that you have felt tired or without energy during the past week, times you have felt tired or without energy for more than 3 hours on any day during the past week, times you have felt so tired that you had to force yourself to do things during the past week, days that you have gone to work sick, search emotions, fatigue and anxiety, exhaustion, cynicism, emotional and cognitive irritation, musculoskeletal problems in the body and extremities and psychophysiological disorders), and negatively with 7 correlates (the comfort of the seat, the suspension of the seat, the adjustable lumbar support of the seat, relaxed driving, prevention of hazards, safety behaviours in the vehicle and functional impulsivity) (see Table 3). 
Table 3

GSQS-8: Correlations between the factor (GSQS-8, external criteria and contrast scales (TDS-38, MBI-GS, Irritation, MP-9, Trans-18 and DII)

\begin{tabular}{|c|c|c|}
\hline & External criteria and contrast scales & F1 $(N=372)$ \\
\hline \multirow[t]{7}{*}{$\begin{array}{l}\text { External } \\
\text { Correlates }\end{array}$} & $\begin{array}{l}\text { How many days have you felt tired or without energy } \\
\text { during the past week? }\end{array}$ & $0.38^{* *}$ \\
\hline & $\begin{array}{l}\text { How many times have you felt tired or without energy } \\
\text { for more than } 3 \text { hours on any day during the past week? }\end{array}$ & $0.39^{* *}$ \\
\hline & $\begin{array}{l}\text { How many times have you felt so tired that you had to } \\
\text { force yourself to do things during the past week? }\end{array}$ & $0.34^{* *}$ \\
\hline & $\begin{array}{l}\text { How many days have you gone to work when you } \\
\text { were sick? }\end{array}$ & $0.17^{* *}$ \\
\hline & $\begin{array}{l}\text { In general, for your work vehicle, the comfort of your } \\
\text { seat (driver's seat) is ... }\end{array}$ & $-0.14^{*}$ \\
\hline & $\begin{array}{l}\text { In general, for your work vehicle, the suspension of } \\
\text { your seat (driver's seat) is ... }\end{array}$ & $-0.18^{* *}$ \\
\hline & $\begin{array}{l}\text { In general, for your work vehicle, the adjustable back } \\
\text { support of the driver's seat is ... }\end{array}$ & $-0.17^{i *}$ \\
\hline \multirow[t]{4}{*}{ TDS-38 } & F1.- Relaxed driving & $\begin{array}{l}-0.31^{* *} \\
-0.18^{* *}\end{array}$ \\
\hline & F3.- Alertness and vigilance & 0.05 \\
\hline & F4.- Search emotions & $0.17^{\text {t* }}$ \\
\hline & F5.- Fatigue and anxiety & $0.30^{* *}$ \\
\hline \multirow[t]{3}{*}{ MBI-GS } & F1.- Exhaustion & $0.37^{\text {*t }}$ \\
\hline & F2.- Cynicism & $.024^{* *}$ \\
\hline & F3.- Personal effectiveness & -0.04 \\
\hline \multirow[t]{2}{*}{ Irritation } & F1.- Emotional & $0.34^{*+}$ \\
\hline & F2.- Cognitive & $0.37^{* *}$ \\
\hline \multirow[t]{3}{*}{ MP-9 } & F1.- Body & $0.21^{\star *}$ \\
\hline & F2.- Extremities & $0.24^{*+}$ \\
\hline & F1.- Psychophysiological disorders & $0.19^{*+}$ \\
\hline \multirow[t]{2}{*}{ Trans-18 } & F2.- Personal safety behaviours & -0.07 \\
\hline & F3.- Safety behaviour in the vehicle & $-0.11^{*}$ \\
\hline \multirow[t]{2}{*}{ DII } & F1.- Functional & $-0.19^{*+}$ \\
\hline & F2.- Dysfunctional & 0 \\
\hline
\end{tabular}

\section{Discussion}

In the present study we present the psychometric properties of the Groningen Sleep Scale (GSQS-15: Meijman et al., 1990). This instrument evaluates subjective sleep quality, covering the following complaints: the general quality of sleep, insufficient sleep, problems falling asleep, problems sleeping and waking up feeling unrested. It is the first time that this scale has been adapted to the Spanish language.

The first objective (to replicate the resulting CFA structure with SEM) was fulfilled because the result was unifactorial like the original Dutch version (Meijman et al., 1990), reducing the number of items from 15 to 8 . This result is supported by the indexes obtained as they all show a good fit $(\mathrm{NFI}=0.902 ; \mathrm{TLI}=0.844 ; \mathrm{CFI}$ $=0.913$; RMSEA $=0.08$ ).

The second objective (confirm the scale's reliability or internal consistency) was also fulfilled because the results show reliability
(0.90), even above the original scale $(\alpha=0.89)$, the scale in Parsi $(\alpha=0.88)$ and the Hungarian scale $(\alpha=0.85)$.

The third objective (to look for evidence of convergent validity) was also fulfilled. The existing correlations can be observed to be directly and inversely associated with both with the different correlates and the instruments used. The scale has good indications of validity with the TDS-38, MBI-GS, Irritation, MP-9, DII and Trans-18 scales. Lower sleep quality was positively related to the days that the driver has felt tired or without energy during the past week $(r=0.38, p<0.01)$, the times they have felt tired or without energy for more than 3 hours on any day during the past week $(r=0.39, p<$ 0.01 ), the times when they felt so tired that they had to force themselves to do things during the last week $(r=0.34, p<0.01)$, the days they went to work when they were sick $(r=0.17$, $p<0.01)$, the search emotions $(r=0.17, p<$ $0.01)$, fatigue and anxiety $(r=0.30, p<0.01)$, exhaustion $(r=0.37, p<0.01)$, cynicism $(r=$ $0.24, p<0.01)$, emotional irritation $(r=0.34$, $p<0.01)$, and cognitive irritability $(r=0.37$, $p<0.01$ ), muscle-skeletal problems in the body $(r=0.21, p<0.01)$ and limbs $(r=0.24, p$ $<0.01)$ and psychophysiological disorders $(r=$ $0.19, p<0.01)$. It was negatively related to the comfort of the seat $(r=0.14, p<0.05)$, the suspension of the seat $(r=-0.18, p<0.01)$, the adjustable lumbar support of the seat $(r=-0.17$, $p<0.01)$, relaxed driving $(r=-0.31, p<0.01)$, hazard prevention $(r=-0.18, p<0.01)$, safety behaviours in the vehicle $(r=-0.11, p<0.05)$ and functional impulsivity $(r=0.19, p<0.01)$.

In conclusion, the different analyses were carried out to provide evidence of a unifactorial structure (quality of sleep) and statistical indexes with proper adjustment (Tabachnick \& Fidell, 2007). The GSQS-8 is an instrument that makes it possible to evaluate the subjective sleep quality of professional drivers. It is an instrument that can be applied and interpreted quickly and is easy to understand. Regarding the applicability, given that the scale has good psychometric properties, the results have important practical implications regarding drivers' quality of sleep and rest. These 
should be considered for adequate Strategic Management of Human Resources to improve occupational health and decrease accidents in the researched sector. Prevention professionals can use this scale to obtain data for making an evaluation based on scientific evidence. As limitations to this research, we find that the number of women who drive professionally is very small in the study population, so it would be convenient to conduct a study with a sample that contained a higher representation of the female gender. New studies would also be necessary to analyse the discriminant validity, carrying them out among groups of workers and professionals of diverse origin competent in the Spanish language. It would also be interesting to analyse the discriminant validity according to the type of vehicle (truck, taxi, bus, and so forth).

\section{References}

Åkerstedt, T., Knutsson, A., Westerholm, P., Theorell, T., Alfredsson, L., \& Kecklund, G. (2002). Sleep disturbances, work stress and work hours. Journal of Psychosomatic Research, 53(3), 741-748. https://doi.org/10 .1016/S0022-3999(02)00333-1

Åkerstedt, T., Knutsson, A., Westerholm, P., Theorell, T., Alfredsson, L., \& Kecklund, G. (2004). Mental fatigue, work and sleep. Journal of Psychosomatic Research, 57(5), 427-433. https://doi.org/10.1016/j.jpsychor es.2003.12.001

Bentler, P. M. (1990). Comparative fit indexes in structural models. Psychological Bulletin, 107, 238-246. https://doi.org/10.1037/0033 $-2909.107 .2 .238$

Berrones, L., \& González, E. (2018). State of the art of the work and health conditions of the professional drivers. Revista Red de Investigación en Salud en el Trabajo, 1(2), 21-29. https://rist.zaragoza.unam.mx/index .php/rist/article/view/26

Boada-Grau, J., Sánchez-García, J. C., PrizmicKuzmica, A. J., \& Vigil-Colet, A. (2012). Health and Safety at Work in the Transport Industry (TRANS-18): Factorial Structure,
Reliability and Validity. The Spanish Journal of Psychology, 15(1), 357-366. https://doi.or g/10.5209/rev_SJOP.2012.v15.n1.37342

Bonnet, M. H. (1985). Effect of sleep disruption on sleep, performance, and mood. Sleep, 8(1), 11-19. https://doi.org/10.1093/sleep/8 .1 .11

Chaiard, J., Deeluea, J., Suksatit, B., \& Songkham, W. (2019). Factors Associated with Sleep Quality of Thai Intercity Bus Drivers. Industrial Health, 2018-0168. https ://doi.org/10.2486/indhealth.2018-0168

Chico, E., Tous, J. M., Lorenzo-Seva, U., \& Vigil-Colet, A. (2003). Spanish adaptation of Dickman's impulsivity inventory: Its relationship to Eysenck's personality questionnaire. Personality and Individual Differences, 35, 1883-1892. https://doi.org/1 0.1016/S0191-8869(03)00037-0

Connor, J., Norton, R., Ameratunga, S., Robinson, E., Civil, I., Dunn, R., Baley, J., \& Jackson, R. (2002). Driver sleepiness and risk of serious injury to car occupants: population based case control study. British Medical Journal, 324, 1125-1125. https://do i.org/10.1136/bmj.324.7346.1125

Davidović, J., Pešić, D., \& Antić, B. (2018). Professional drivers' fatigue as a problem of the modern era. Transportation Research Part F: Traffic Psychology and Behaviour, 55, 199-209. https://doi.org/10.1016/j.trf.2018. 03.010

Dickman, S. J. (1990). Functional and dysfunctional impulsivity: Personality and cognitive correlates. Journal of Personality and Social Psychology, 58(1), 95-102. https:/ /doi.org/10.1037/0022-3514.58.1.95

Dirección General de Tráfico (DGT). (2006). El sueño es una de las principales causas de accidente en carretera. Ministerio del Interior. http://www.dgt.es/es/la-dgt/campa nas/2006/El-suenio-es-una-de-las-principal es-causas-de-accidente-en-carretera.shtml

Dirección General de Tráfico (DGT). (2018). Las salidas de vía y colisiones frontales causan 652 muertes en carreteras convencionales. Ministerio del Interior. http://www.dgt.es/es 
/prensa/notas-de-prensa/2018/20180816

NP-Siniestralidad-convencionales.shtml

Dorn, L., Stephen, L., af Wåhlberg, A., \& Gandolfi, J. (2010). Development and Validation of a Self Reported Measure of Bus Driver Behavior. Ergomics, 53(12), 1420-1433. https://doi.org/10.1080/001401 39.2010 .532882

Fan, X., \& Sivo, S. A. (2007). Sensitivity of fit indices to model misspecification and model types. Multivariate Behavioral Research, 42, 509-529. https://doi.org/10.10 80/00273170701382864

Filtness, A. J., Anund, A., Fors, C., Ahlström, C., Åkerstedt, T., \& Kecklund, G. (2014). Sleep-related eye symptoms and their potential for identifying driver sleepiness. Journal of Sleep Research, 23(5), 568-575. h ttps://doi.org/10.1111/jsr.12163

Gosselin, A., De Koninck, J., \& Campbell, K. B. (2005). Total sleep deprivation and novelty processing: Implications for frontal lobe functioning. Clinical Neurophysiology, 116(1), 211-222. https://doi.org/10.1016/j. clinph.2004.07.033

Hambleton, R. K., Merenda, P. F., \& Spielberger, C. D. (2005). Adapting educational and psychological tests for cross-cultural assessment. Lawrence Erlbaum Associates.

Hernández, R., Fernández, C., \& Baptista, P. (2004). Metodología de la Investigación. McGraw-Hill Interamericana.

Hillman, D., Mitchell, S., Streatfeild, J., Burns, C., Bruck, D., \& Pezzullo, L. (2018). The economic cost of inadequate sleep. Sleep, 41 (8), 1-13. https://doi.org/10.1093/sleep/z sy083

Hu, L. T., \& Bentler, P. M. (1999). Cutoff criteria for fit indexes in covariance structure analysis: Conventional criteria versus new alternatives. Structural Equation Modeling, 6, 1-55. https://doi.org/10.1080/107055199 09540118

Jafarian, S., Gorouhi, F., Taghva, A., \& Lotfi, J. (2008). High-altitude sleep disturbance: Results of the Groningen Sleep Quality Questionnaire survey. Sleep Medicine, 9(4),
446-449. https://doi.org/10.1016/j.sleep.20 07.06.017

Kaiser, H. F. (1974). An index of factorial simplicity. Psychometrika, 39, 31-36. https:// doi.org/10.1007/BF02291575

Kecklund, G., \& Åkerstedt, T. (2004). Apprehension of the subsequent working day is associated with a low amount of slow wave sleep. Biological Psychology, 66(2), 169-176. https://doi.org/10.1016/j.biopsych o.2003.10.004

Kerlinger, F. N., \& Lee, H. B. (2004). Behavior Research. Research methods in social sciences. McGraw-Hill.

Lattin, J., Carroll, J., \& Green, P. (2003). Analyzing multivariate data. Duxbury Press.

Lévy-Mangin, J.-P., \& Varela-Mallou, J. (2006). Modelización con estructuras de covarianzas en ciencias sociales\#: temas esenciales, avanzados y aportaciones especiales. In Modelización con estructuras de covarianzas en ciencias sociales\#: temas esenciales, avanzados y aportaciones especiales. Gesbiblo, S.L.

Li, M. K., Yu, J. J., Ma, L., \& Zhang, W. (2019). Modeling and mitigating fatigue-related accident risk of taxi drivers. Accident Analysis and Prevention, 123, 79-87. https:// doi.org/10.1016/j.aap.2018.11.001

Li, Y., Yamamoto, T., \& Zhang, G. (2018). Understanding factors associated with misclassification of fatigue-related accidents in police record. Journal of Safety Research, 64, 155-162. https://doi.org/10.10 16/j.jsr.2017.12.002

Lorenzo-Seva, U. (1999). Promin: A method for oblique factor rotation. Multivariate Behavioral Research, 34, 347-365. https://do i.org/10.1207/S15327906MBR3403_3

McVicar, A. (2003). Workplace stress in nursing: A literature review. Journal of Advanced Nursing, 44(6), 633-642. https://doi.org/10. 1046/j.0309-2402.2003.02853.x

Meijman, T., de Vries-Griever, A., De Vries, G., \& Kampman, R. (1988). The evaluation of the Groningen Sleep Quality Scale. Groningen: Heymans Bulletin, HB 88-13-EX. 
Meijman, T. F., Thunnissen, M. J., \& De VriesGriever, A. G. H. (1990). The after-effects of a prolonged period of day-sleep on subjective sleep quality. Work and Stress, 4(1), 65-70. https://doi.org/10.1080/02678 379008256965

Merino, E., Carbonero, M. Á., Moreno-Jiménez, B., \& Morante, M. E. (2006). La Escala de Irritación como instrumento de evaluación del estrés laboral. [Irritation: Analysis of an instrument to assess stress at work]. Psicothema, 18, 419-424. http://www.ncbi.n lm.nih.gov/pubmed/17296066

Michael, J. T. (2017). Classification of sleep disorders. In Sleep ans Psychosomatic Medicine (pp. 1-11). SRS Press.

Miró, E., \& Buela-Casal, G. (2005). Sueño, estrés y trabajo. In J. L. Arco (Ed.), Estrés y trabajo: cómo hacerlos compatibles (pp. 87-115). Junta de Andalucía, Consejería de Justicia y Administración Pública.

Mohr, A. (1986). Die Durchsetzung der Politikwissenschaft an deutschen Hochschulen und die Entwicklung der Deutschen Vereinigung für Politische Wissenschaft. In Politikwissenschaft in der Bundesrepublik Deutschland (pp. 62-77). VS Verlag für Sozialwissenschaften. https://doi .org/10.1007/978-3-663-11075-0_4

Mohr, G., Rigotti, T., Müller, A., Tschan, F., \& Aycan, Z. (2006). The Assessment of Psychological Strain in Work Contexts. European Journal of Psychological Assessment, 22 (3), 198-206. https://doi.org/10.1027/10 15-5759.22.3.198

Moya-Albiol, L., Serrano, M. A., González-Bono, E., Rodríguez-Alarcón, G., \& Salvador, A. (2005). Respuesta psicofisiológica del stress en una jornada laboral. Psycothema, 17(2), 205-211. https://dialnet.unirioja.es/servlet/ articulo? codigo $=1128134$

Mulder-Hajonides van der Meulen, R. E. (1990). The Groningen sleep quality scale. Scandinovian Journal of Psychiatry, (Submited).

Muñiz, J., \& Bartram, D. (2007). Improving international tests and testing. European
Psychologist, 12, 206-219. https://doi.org/10 $.1027 / 1016-9040.12 .3 .206$

Nunnally, J. C., \& Bernstein, I. H. (1994). Psychometric Theory (McGraw-Hill Series in Psychology). McGraw-Hill. https://doi.org/1 $0.1037 / 018882$

Robb, M. J. M., \& Mansfield, N. J. (2007). Self-reported musculoskeletal problems amongst professional truck drivers. Ergonomics, 50(6), 814-827. https://doi.org/ $10.1080 / 00140130701220341$

Robert-Sentís, L. (2016). Salud laboral en conductores profesionales del transporte por carretera [Occupational health of professional road transport drivers]. (Doctoral thesis not published). Universitat Rovira i Virgili, Tarragona (Spain).

Salanova, M., Schaufeli, W. B., Llorens, S., Peiró, J. M., \& Grau, R. (2000). Desde el "burnout" al "Engagement" iuna nueva perspectiva?. Journal of Work and Organizational Psychology, 16(2), 117-134.

Simor, P., Köteles, F., Bódizs, R., \& Bárdos, G. (2009). A questionnaire based study of subjective sleep quality: The psychometric evaluation of the Hungarian version of the Groningen Sleep Quality Scale. Mentalhigiene Es Pszichoszomatika, 10(3), 249-261. https://doi.org/10.1556/Mental.1 0.2009 .3 .5

Sluiter, J. K., Van Der Beek, A. J., \& FringsDresen, M. H. W. (1999). The influence of work characteristics on the need for recovery and experienced health: A study on coach drivers. Ergonomics, 42, 573-583. https://doi.org/10.1080/001401399185487

Sunwoo, J. S., Hwangbo, Y., Kim, W. J., Chu, M. K., Yun, C. H., \& Yang, K. I. (2017). Sleep characteristics associated with drowsy driving. Sleep Medicine, 40, 4-10. https://do i.org/10.1016/j.sleep.2017.08.020

Tabachnick, B. G., \& Fidell, L. S. (2007). Using multivariate statistics, 5th ed. In Using multivariate statistics, 5th ed. Allyn \& Bacon/ Pearson Education. http://psycnet.apa.org/r ecord/2006-03883-000

Taylor, A. H., \& Dorn, L. (2006). Stress, fatigue, health, and risk of road traffic 
accidents among professional drivers: The Contribution of Physical Inactivity. Annual Review of Public Health, 27(1), 371-391. https://doi.org/10.1146/annurev. publhealth.27.021405.102117

Timmerman, M. E., \& Lorenzo-Seva, U. (2011). Dimensionality assessment of ordered polytomous items with parallel analysis. Psychological Methods, 16, 209-220. https:// doi.org/10.1037/a0023353

Useche, S. A., Cendales, B. E., \& Gómez, V. (2017). Measuring Fatigue and its Associations with Job Stress, Health and Traffic Accidents in Professional Drivers: The Case of BRT Operators. EC Neurology, 4(4), 103-118.

Velicer, W. F. (1976). Determining the number of components from the matrix of partial correlations. Psychometrika, 41, 321-327. ht tps://doi.org/10.1007/BF02293557

\section{Notes}

* Research article. 